\title{
Urgent Biophilia: Human-Nature Interactions and Biological Attractions in Disaster Resilience
}

\author{
Keith G. Tidball $^{1}$
}

\begin{abstract}
This contribution builds upon contemporary work on principles of biological attraction as well as earlier work on biophilia while synthesizing literatures on restorative environments, community-based ecological restoration, and both community and social-ecological disaster resilience. It suggests that when humans, faced with a disaster, as individuals and as communities and populations, seek engagement with nature to further their efforts to summon and demonstrate resilience in the face of a crisis, they exemplify an urgent biophilia. This urgent biophilia represents an important set of human-nature interactions in SES characterized by hazard, disaster, or vulnerability, often appearing in the 'backloop' of the adaptive cycle. The relationships that human-nature interactions have to other components within interdependent systems at many different scales may be one critical source of resilience in disaster and related contexts. In other words, the affinity we humans have for the rest of nature, the process of remembering that attraction, and the urge to express it through creation of restorative environments, which may also restore or increase ecological function, may confer resilience across multiple scales. In making this argument, the paper also represents a novel contribution to further theorizing alternatives to anthropocentric understandings of human-nature relations, and strongly makes the case for humans as part of, not separate from, ecosystems.
\end{abstract}

Key Words: biophilia, disaster, human-nature interaction, resilience, urgent biophilia

\section{INTRODUCTION}

Can community-based ecological restoration, sometimes referred to as human-nature interactions or greening, help us begin to understand the importance of biological attraction principles in resilience thinking, especially in areas that have experienced hazards and disasters? We know that human societies have been beset with hazards and disasters for thousands of years (Diamond 2005, Reilly 2009), and have had to adapt to survive them. We have also seen how interactions among humans and other biophysical elements of social-ecological systems play a role in recovery and resilience after surprise and rapid change brought about by geophysical, technological, political, or other disasters (Tidball and Krasny $2012 a$ ). Thus, disasters provide "a unique view of a society's capacity for resistance or resilience in the face of disruption" (Oliver-Smith and Hoffman 2002:10), and a lens through which to observe the importance of human-nature interactions and biological attractions in these contexts.

In the 21st century, some argue that humans are now bringing about disasters in unprecedented scope and scale (OliverSmith 2002, Zhang et al. 2007). A few decades ago, Lewis and Sturgill (1979:330) warned that humans are living in "two worlds ... within the envelope of our skin is a biological entity which, through evolution, has been tuned for survival in natural environments ... [yet] around us lies not the green world in which we learned to survive and carry forward our species, but rather a world of our own creation, built of inert materials," alluding to the possibilities of disasters born, in part, of our own short-sightedness. More recently, Gibbs (2009:329) reminded us that "it is the events that are not well foreseen and therefore not perceived to be a threat that are likely to expose a lack of resilience ... [t]hus, it is the large and often unforeseen perturbations that can expose resilience [emphasis added]."

Therefore, do we remember in some way the lessons of Lewis and Sturgill's green world and deploy that memory when confronted with catastrophe (Tidball et al. 2010)? I have argued, along with many colleagues, (Tidball and Krasny 2012a), that human-nature interactions may represent a suite of human adaptations to hazards and disasters, including geophysical events, war, acts of genocide or persecution, among others (Vayda and McCay 1975, Hoffman and OliverSmith 2002), and that applying observations from both the literature on resilience in human development (Masten et al. 1990) and the literature on resilience in social-ecological systems (SES; cf. Walker et al. 2004 among many others) may be useful in addressing diverse massive-scale hazards, such as a flu pandemic, ethnic conflict and war, or natural disasters, where interdependent adaptive systems at multiple levels, from cellular to global, face destruction (Masten and Obradovic 2008). By explicitly integrating these linked notions of resilience and vulnerability, in this paper I attempt to address the continued lack of integration regarding insights around adaptation and transformation from unique scientific approaches (Miller et al. 2010) while contributing to the literature connecting individual resilience to the adaptive functioning of larger social systems and networks, such as neighborhoods or socio-cultural systems, which, as Masten and Obradovic (2008) have pointed out, is scarce. 
Fig. 1. As adapted from Holling and Gunderson (2002) a stylized depiction of the four ecosystem functions ( r, K, $\omega$, $\alpha$ ) and the flow of events among them. Arrows show flow speed in the cycle; closely spaced arrows represent slow change and long arrows represent rapid change. The cycle reflects change in two properties (1) the Y axis is potential inherent in accumulated resources; (2) the $\mathrm{X}$ axis is the degree of connected among controlling variables. The transition from the $\mathrm{K}$ phase to the $\omega$ phase is depicted here as 'The Red Zone.' Expression of biophilia or biological attraction is also represented, corresponding to the $\mathrm{Y}$ axis and potential. Low connectedness is associated with loosely connected elements whose behavior is dominated by external relations and variability. High connectedness is associated with elements whose behavior is dominated by internal relations that control or mediate external variability. The 'back loop,' in green, represents the stages during which urgent biophilia is likely expressed. The exit from the cycle at the left of the figure suggests the stage where the potential can leak away and where a 'flip' into a less organized and desirable system is likely. (Reproduced with permission of Island Press, Washington, DC.)

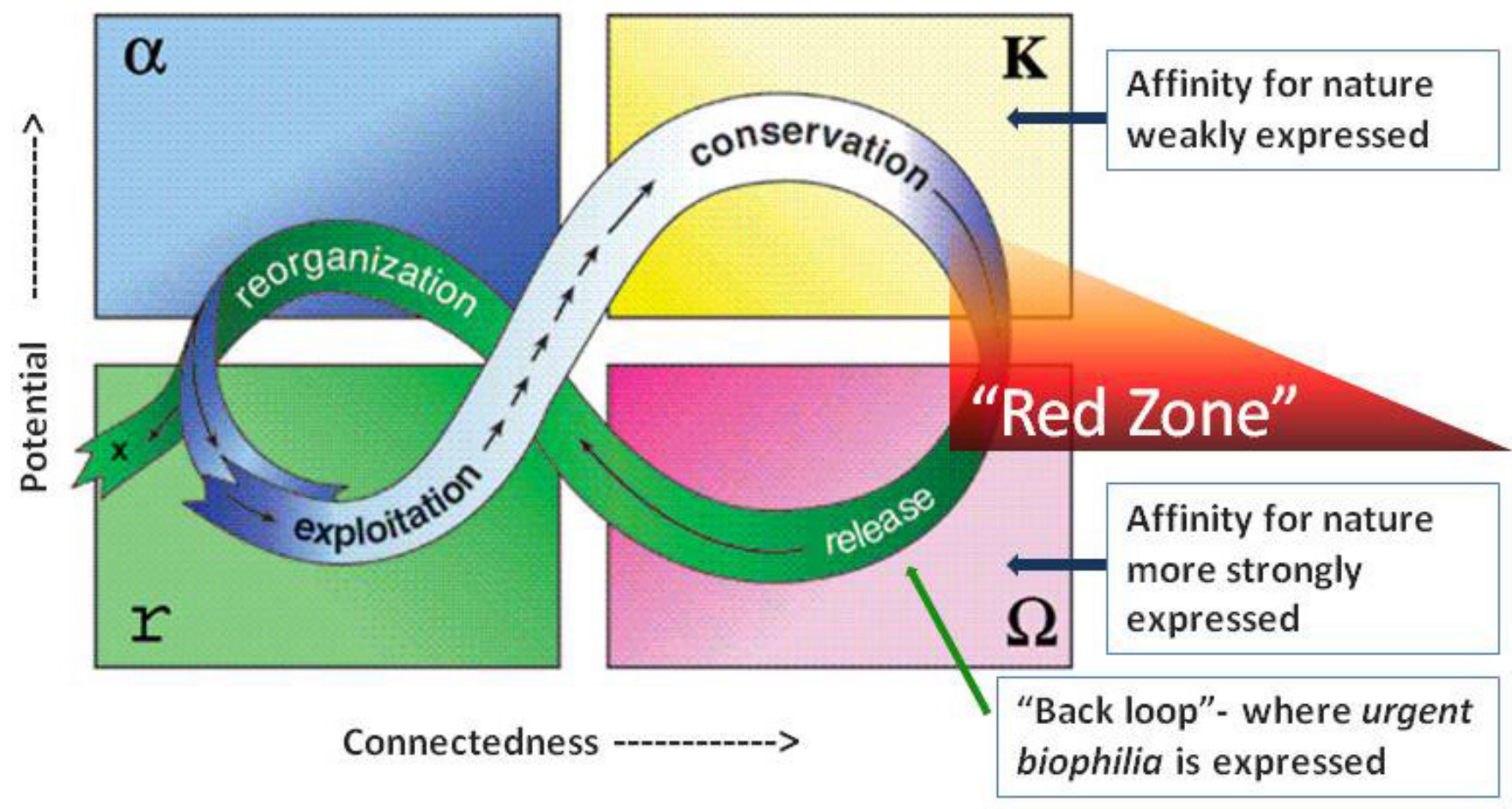

In this paper, I propose a nuanced addition to the idea of biophilia (Wilson 1984, Kellert and Wilson 1993). By augmenting biophilia with new ideas about biological attraction (Agnati et al. 2009a), I suggest that when humans, faced with urgent disaster or hazard situations, as individuals and as communities and populations, seek out doses of contact and engagement with nature to further their efforts to summon and demonstrate resilience in the face of a crisis, they exemplify an urgent biophilia. This urgent biophilia represents an important set of human-nature interactions in SES experiencing hazard, disaster, or vulnerability, often appearing in the 'backloop' (see Fig. 1) of the adaptive cycle (Holling and Gunderson 2002). The relationships those human-nature interactions have to other components within interdependent systems at many different scales, may be one critical source of resilience after dramatic surprise or sudden change. In other words, the affinity we humans have for the rest of nature, the process of remembering that affinity and the urge to express it through creation of restorative environments, which may also restore or increase ecological function, may confer resilience across multiple scales. Through this expression of perhaps "humanity's single most powerful idea - that we are not at the center of anything ... and also our most humbling idea, that all of life on earth is kin" (Reece Hardy et al. 2009:16) we may find important insights into the value of human-nature interactions beyond those that become highly visible in hazard, disaster, and vulnerability contexts. This paper is not based primarily on empirical evidence, but rather on a combination of literatures attempting a transformative theory. 


\section{BACKGROUND AND CONTEXT}

It is certainly true that personal safety and security are of paramount concern in hazard and disaster contexts, as are basic and fundamental services like food and water supplies, medical support, and basic infrastructure function (IFRC 2004). It is also well known that postdisaster planning brings its own set of challenges (Tidball et al. 2008, Tidball and Weinstein 2011). Like other events that radically affect communities, e.g., closing of a factory in a manufacturing town (see Stedman and Ingalls 2012), disasters are known to exacerbate existing inequalities (Peacock et al. 1997, Pelling 2003, Blaikie et al. 2003, Drennan 2007). Sudden disasters often destroy the physical infrastructure of marginalized or vulnerable communities (Adger et al. 2005, Daniels et al. 2006) and can severely strain social networks (Walker and Meyers 2004). Furthermore, survivors of the disaster experience considerable psychological trauma that is difficult for responders to fully understand or skillfully negotiate (Sattler et al. 1997, Inter-Agency Standing Committee 2007). In light of these challenges, it is remarkable how often one hears of stories where people have had an almost immediate 'green response' to a crisis, forming a community garden in the case of war veterans and widows in Bosnia (Brdanovic 2009), growing a few flowers in the trenches of World War I (Helphand 2006), or tending to trees that survived in Hiroshima at the end of World War II (Cheng and McBride 2006).

Despite the obvious survival implications of planting food and tending trees, given the hardships and urgent safety issues faced by civilians, soldiers, and first-responders after a disaster or during war, it seems to some counterintuitive that they would engage in the simple act of gardening, tree planting, or other greening activities. However, intriguing and compelling examples exist of people, stunned by a crisis, benefitting from the therapeutic qualities of nature contact to ease trauma and to aid the process of recovery (Miavitz 1998, Hewson 2001). A large literature explains the benefits of horticulture therapy more generally (Markee and Janick 1979, Relf 1992, 2005, Relf and Dorn 1995), as well as in more specific contexts such as among returning war veterans (Helphand 2012, Krasny et al. 2012), in refugee contexts (Moore 2012), and in prisons (Lindemuth 2012) to name a few. Beyond the therapeutic value of plants themselves, others have researched the value of green places, or restorative environments (Hartig and Staats 2003) to ease trauma or discomfort (Ulrich 1983, Kaplan and Kaplan 1989).

However, what might tree planting, habitat restoration, community gardening, and other greening activities contribute to individual or SES resilience in hazard, disaster, and vulnerability contexts? In much of the research and practice conducted under the rubric of horticultural therapy, the individual person in need of an intervention is considered a patient who is prescribed horticultural interventions by a professional practitioner. Moving toward an 'ecological' approach, researchers in the field of systemic therapies have proposed alternative strategies for healing, conducted in creative ways in nature, that address the environment not merely as a setting but as a partner in the process (Berger and McLeod 2006). In the context of SES resilience with its focus on emergent or self-organized processes, the attempt here is to move one step further toward linking consideration of individuals with consideration of groups of people, neighborhoods, and communities, who find contact with nature of their own volition, a self-administered therapy, as a means to cope with the aftermath of a disaster, crisis, or conflict. In so doing, I hope to contribute to the literature connecting individual resilience to the adaptive functioning of larger social systems and networks, such as neighborhoods or socio-cultural systems (Masten and Obradović 2008).

If it is true that, at least in the short term, 'all disasters are local,' (Ganyard 2009) and that, similarly, as Masten and Obradovic (2008) have argued, "all human resilience is local, emerging from the actions of individuals and small groups of people, in relation to each other and powered by the adaptive systems of human life [emphasis added] and development," then we must look to that to which human life has adapted for clues about sources of emergent human resilience. Humans have adapted to both larger and smaller living systems and subsystems with which we share interdependence, and according to both E. O. Wilson (1984) and Luigi Agnati and colleagues (2009a), we seem to have an affinity for those living systems, and arguably they to us. At the same time, some scholars claim that "there is substantial evidence to suggest that, as a species, our modern lifestyle may have strayed too far from that to which we have adapted" (Gullone 2000:315). Masten and Obradovic (2008) acknowledge that a variety of systems facilitate human resilience, especially in postdisaster and related contexts, but seem to agree with Longstaff (2005) that those systems are unlikely to be directly available during an unfolding disaster. Their description of these systems includes primarily manufactured ones, such as communication, transportation, manufacturing, and others, and not ecological systems. However, what if we included in this list of systems that facilitate resilience, especially after a disaster, locally available biological and ecological systems, subsystems, and components, from the smallest to the largest, from the most simple to the most complex? After all, at least according to Kurakin (2009), "the structures and dynamics of all living organizations, from proteins and cells to societies and ecologies, embody their evolutionary histories [and] memories." What if, in terms of human resilience, we focused on the nearly scale-free property of life itself, of the compulsion to live, of living (Agnati et al. 2009a; A. Kurakin, unpublished manuscript)?

At this point, it is important to briefly operationalize two terms that appear frequently in this paper, greening and resilience. 
When speaking of greening, I refer to an active and integrated approach to the appreciation, stewardship, and management of living elements of social-ecological systems. While recognizing the importance of green political thought ${ }^{[1]}$ and of a growing interest in a 'green economy' (Pearce et al. 1992, Milani 2000), in this paper the focus is on initiatives that emerge in a context of self-organized community development and community-based ecological restoration. In fact, perhaps a significant accomplishment of such locally emergent greening practices, in particular the more participatory forms embodied in many community gardens in large cities (Schmelzkopf 1995; Saldivar-Tanaka and Krasny 2004) and in tree planting efforts in neighborhoods of post-Katrina New Orleans (Tidball et al. 2010), is the mainstream acceptance of much of green political thought. The philosopher Andrew Light (2003) has captured this notion in his description of how environmental stewardship efforts are defining a new environmental movement; this civic environmental movement finds its inspiration in the work of urban "community greeners.

This paper will not be dealing in much depth or detail with political or philosophical dimensions of greening, nor delve solely or too deeply into the broad field of horticulture, which concerns itself with growing plants in cities for ornamentation and other purposes (Tukey 1983). Rather than focus strictly on utilization of plants, the emphasis here is upon active cultivation within a social-ecological or community context, going beyond the ornamental and instrumental uses of plants and nature to suggest that human relationships with plants, animals, and landscapes have a role to play in urban and other settings faced with hazard, disaster, or vulnerability.

Scholars writing about SES resilience have identified four factors as critical to fostering resilience during periods of change and reorganization: (1) learning to live with change and uncertainty; (2) nurturing biological and cultural diversity; (3) combining different types of knowledge for learning; and (4) creating opportunity for self-organization (Folke et al. 2002). In previous work my colleague and I have proposed the term 'civic ecology' (Tidball and Krasny 2007, Krasny and Tidball 2012) and associated 'civic ecology practices' (Krasny and Tidball 2010) to describe community-based greening efforts that address these and other factors fostering SES resilience. We define civic ecology as the study of feedbacks and other interactions among four components of a SES: (1) community-based environmental stewardship (civic ecology practice); (2) education and learning situated in these practices (civic ecology education); (3) the people and institutions involved; and (4) the ecosystem services produced by the people, their stewardship, and educational practices (Tidball and Krasny 2007, Tidball and Krasny 2011). Civic ecology practices integrate local stewardship activities, such as planting community or allotment gardens or monitoring local biodiversity, with learning from multiple forms of knowledge including that of community members and scientists or other experts. Such practices often lead to civic activism such as advocating for green spaces as a means to reduce crime and violence. From the perspective of greening in hazard, disaster, and vulnerability contexts, civic ecology emphasizes creating conditions whereby existing community assets can be leveraged to foster SES resilience prior to and following hazard, disaster, and vulnerability scenarios in cities and in other SES.

Thus, it is in examining people's efforts to navigate journeys of resilience through urgent circumstances that we explore individual and community yearning for and subsequent expression of an affinity for other living things. These doses of nature go beyond simply nature contact (Louv 2005) to encompass active engagement in restoring nature in concert with other members of one's community, for example through urban community forestry and community gardening. I acknowledge claims that not all people recognize or act upon this affinity for nature, and for those that do, such reactions may vary according to circumstance (Kellert 1997a).

Following Kellert in his book Building for Life (2005) and taking his ideas a step further into the realms of recovery and resilience postcrisis, in this paper I explore how expressing biological attraction through creating restorative environments might usher in and reinforce "... a respect for all values and benefits we derive from nature ..." thereby reflecting "... a dependence [upon living systems] that extends far beyond a narrow materialistic and economic calculus to embrace a broader conception of human self-interest" (Kellert 2005:180). This would enable recognition of "the widest range of values derived from our dependence on nature, one that also includes emotional connection, intellectual competence, the experience of beauty, a sound moral compass, and a world of enduring meaning and relation" (Kellert 2005:180). Based on my personal experience, too often recognition of these values, and opportunities to express them, are in short supply in hazard, disaster, or vulnerability contexts.

To build the argument about the importance of human-nature interaction in postdisaster or hazard recovery and resilience I briefly review the literature on restorative environments, biophilia, and biological attraction principles, and deploy these notions in terms of social-ecological interventions and responses in disaster settings. After briefly exploring linkages between the concept of biological attraction and the notion of cultivating resilience, I turn to the SES resilience literature as it applies to expressing biological attraction in disaster and conflict scenarios. I conclude with a synthesis in which a hypothesis about the importance of urgent biophilia as it relates to SES resilience is forwarded. Given that this contribution is intentionally exploratory rather than data-driven, the intent is to stimulate thinking about the origin and role of greening in building adaptive capacity during and after conflict or disaster, 
rather than to present results of studies attempting to prove this phenomenon, though I hope such studies will be forthcoming.

\section{RESTORATIVE ENVIRONMENTS}

Though some scholars see human interaction with the landscape, such as gardening, as a form of human dominance over nature (cf., for example, Riley 1992), I have chosen to set aside such arguments that I feel may reinforce unhelpful dichotomies regarding humans and nature, and that may exacerbate the problems of human exemptionalism and exceptionalism that one might argue are underlying causes for hazards, disasters, and human vulnerability. Rather, I turn to Frumkin (2001) and Hartig (2007) who have traced the idea of human-nature relationships as contributing to human health from the writings of the ancient Greeks, to the New England transcendentalists (Nash 1982, McLuhan 1994, Murphy et al. 1998, Mazel 2000), and through the American landscape designers Andrew Jackson Downing (1869) and Frederick Law Olmsted (1865/1952). Frumkin (2001) relates to us how, a century ago, the early American conservationist John Muir observed, "Thousands of tired, nerve-shaken, over-civilized people are beginning to find out that going to the mountains is going home; that wilderness is a necessity; and that mountain parks and reservations are useful not only as fountains of timber and irrigating rivers, but as fountains of life" (Fox 1981:116). Similarly, Hartig (2007) traces theories about how some natural environments promote restoration and in turn the health of individuals and populations to the writings of Andrew Jackson Downing (1869) and Frederick Law Olmsted (1865/1952).

Hartig and Staats (2003) noted that the idea of restorative environments has caught the attention of increasing numbers of environmental psychologists, as well as researchers in the environment-behavior-design (Betrabet 1996, Cooper Marcus and Barnes 1999) and public health fields (e.g., Frumkin 2001, King et al. 2002, Svendsen and Campbell 2005). According to Hartig and Staats (2003), the study of restorative environments complements research on the conditions in which our functional resources and capabilities diminish, such as what I refer to as 'red zone' contexts like natural disasters and war (Tidball and Krasny 2012b). Hartig and Staats (2003) argue that this complementarity has theoretical and practical aspects; the theoretical aspect involves specifying those qualities of person-environment transactions that promote restoration (precedents acknowledged by Hartig and Staats in this effort include work by Berlyne 1960, Driver and Knopf 1976, Kaplan and Kaplan 1989, Kaplan and Talbot 1983, and Ulrich 1983). Hartig and Staats (2003) call for further work that would reinforce the understanding that an absence of those demands or conditions that make a red zone a red zone, i.e., massive numbers of casualties or deaths, large scale damage to landscapes and ecosystem properties and functions, etc., were that possible, would not necessarily make for an optimal restorative environment. In practical terms, they argue that the elimination of physical, social, and temporal conditions that impose unwanted demands, red zone conditions if you will, does not necessarily leave us with a restorative environment. Rather, Hartig and Staats (2003) claim that, following the lead of Frederick Law Olmsted, planners, landscape architects, land managers, public health workers, politicians, and others can make efforts to modify, maintain, and regulate environments so that they not only present fewer unwanted demands, but also have physical, social, and temporal characteristics that promote restoration (see e.g., Brett et al. 2007).

More recently, studies (Hartig and Staats 2006, Van Den Berg et al. 2007, Bell et al. 2008) have shown that the ability to see or actively experience green spaces can, among other things, reduce domestic violence, quicken healing times, reduce stress, improve physical health, and bring about cognitive and psychological benefits in individuals (Ulrich 1984, Kaplan and Kaplan 1989, Hartig et al. 1991, Sullivan and Kuo 1996, Faber Taylor et al. 1998, Wells 2000) and populations as a whole (Hartig et al. 1991, Branas et al. 2011). For example, a recent 10 -year study has indicated that greening may reduce certain crimes while promoting some aspects of health (Branas et al. 2011). Despite some claims that green spaces can be perceived as dangerous (Herzog and Flynn-Smith 2001, Van Winsum-Westra and Boer 2004), Maas and colleagues (2009) concluded that green space in people's living environment is generally associated with enhanced feelings of social safety and that this relationship is concurrent with the positive relationship between green space and people's health that has been found in the literature. Kuo et al. (1998) and Kuo and Sullivan (2001) present research demonstrating that exposure to trees in urban settings can foster a sense of safety and reduce crime rates, thus contributing to social well-being. Therefore, considering the voluminous research reviewed above, the 'seeing green' implications for human health and well-being of so-called 'plant-people interactions' (Salick 1995, Elings 2006, Relf 2006) appear to be well documented.

However, is there more to this story than the value of 'seeing green'? What about 'doing green'? Most relevant to my interests, and building on research on restorative environments (Ulrich 1983, Ulrich 1984, Kaplan and Kaplan 1989), Helphand (2006:12) claims that the act of gardening historically has been a means for soldiers and victims of war to fight back for their own mental well-being, and for the disenfranchised to become involved in acts of defiance resisting "not only environmental difficulty but also social, psychological, political, or economic conditions." This is consistent with what my colleagues and I have argued elsewhere, that civic ecology practices, including urban community forestry, community gardening, and other selforganized forms of stewardship of green spaces in cities (Tidball and Krasny 2007) are manifestations of how social 
and ecological memories can be instrumentalized through social learning to foster SES resilience following crisis and disaster (Tidball et al. 2010). We proposed that civic ecology communities of practice (cf. Wenger et al. 2002, Wenger 2003) that emerge within and across red zones help to leverage these social-ecological memories (Barthel et al. 2012) into effective practices, and that such communities of practice serve as urban iterations or analogs of the collaborative and adaptive management practices that play a role in SES resilience in more rural communities (Berkes et al. 2003, Davidson-Hunt and Berkes 2003). Others have also highlighted various values of doing green for enhancing human health and well-being (Miles et al. 1998, Austin and Kaplan 2003, Ryan and Grese 2005); many examples of this are found in the edited volume Greening in the Red Zone (Tidball and Krasny 2012a).

A question may arise at this point about the availability of the benefits of seeing green and doing green to more than just individual humans. Although therapy, rehabilitation, and restorative environments involve focusing on the specific needs of individuals, and working with the restorative environments proximate to individuals can serve the goals of therapy or rehabilitation (Cimprich 1993), Hartig (2007:4) argues that by focusing on recurring human needs for restoration:

...our scope of application opens to the population [emphasis added] and, as with other public health interventions, changes the living environment of that population. It is not necessary to work with each and every individual in the population in some deliberate way. Improving the availability of settings that support restoration can have positive effects on the health of the population as a whole, if not on every individual within the population ... Especially in the urban areas where populations have increasingly concentrated, we can promote the health of people by providing opportunities to quickly, easily and regularly access places that support restoration, including but not limited to gardens, parks and forests.

This movement from the individual to the community or even the population level, is echoed in the social science sphere by Granovetter (1973), who in stating "personal experience of individuals is closely bound up with larger-scale aspects of social structure, well beyond the purview or control of particular individuals" (Granovetter 1973:1377), provides further impetus for exploring the role of greening activities at the community and larger scales in hazard, disaster, and vulnerability contexts. Further elaboration and analysis of this scaling up to the community level of the benefits of green space is found in two recent studies of green space in Stockholm (Barthel et al. 2005; Ernstson et al. 2008).

\section{BIOPHILIA AND BIOLOGICAL ATTRACTION PRINCIPLES}

Documentation of notions of the benefits of seeing or doing green can be traced to the aforementioned early works of Stephen and Rachel Kaplan (1989) and Roger Ulrich (1983, 1984) in restorative environments, and seem to resonate with Wilson's (1984) biophilia hypothesis in which he suggests that biophilia describes the connections that human beings subconsciously seek with the rest of life. This biophilia idea is an important reflection of broader efforts to correct what many argue are mistaken assumptions about the origins and ramifications of human dominance in the biosphere. In this domain, Wilson and his colleagues accomplished two things. First, they identified a phenomenon, i.e., that humans have an affinity for other living things. Second, they proposed the possibility that the phenomenon of humans having deep affiliations with nature is rooted in our biology (Kellert and Wilson 1993). These two observations should not be surprising given our evolutionary past, a past in which we evolved with the rest of the biosphere, not separate from it or exempt from its laws, and may be useful in efforts to escape the problems and traps of the human-nature dichotomy and the mythology of human exemptionalism and exceptionalism (Dunlap 1980, Dunlap and Catton Jr. 1994, Vitousek et al. 1997, Williams 2007). The connection between Wilson's biophilia hypothesis and the work of the Kaplans and Ulrich is explicitly made by Ke-Tsung (2001), who argued that both Ulrich's and the Kaplans' theories are based on an evolutionary perspective. Wilson's hypothesis has been acknowledged (van den Born et al. 2001) to have found empirical support (for example, Kaplan 1995, Kahn 1999). Gullone (2000) argues that the research related to biophilia to date is consistent with the proposal that predispositions that evolved in our ancestral environment continue to be present today despite their apparently more limited relevance for modern humans. Further, as Masten and Obradovic (2008) remind us, "the adaptive systems for positive human adaptation and development, legacies of biological and cultural evolution [emphasis added], must be considered and enjoined to promote resilience."

Wilson's (1984) notion of biophilia provides an early attempt at explanation for the restorative value of nature contact. First used by Erich Fromm (1964) to describe a psychological orientation of being attracted to all that is alive and vital, the term, and the book by the same name, attempted to shed light on "how the human tendency to relate with life and natural processes might be the expression of a biological need" (Kellert 1993:20). Wilson suggested the possibility that the deep affiliations humans have with nature are part of our evolutionary past. As opposed to phobias, which are the aversions and fears that people have of things in the natural world, philias are the attractions and positive feelings that people have toward certain habitats, activities, and objects in 
their natural surroundings. Wilson elsewhere argued that some behaviors are at least partly inherited and can be affected by natural selection, and that these behaviors have evolved over time, similar to the way that physical traits are thought to have evolved (Wilson 1975). This sociobiological perspective has been hotly contested since its initial presentation by Wilson and his colleagues (Allen et al. 1975, Lewontin et al. 1984, Segerstråle 2000).

However, it is important to note that Wilson and others describe both an innate and a learned component of biophilia, suggesting that biophilia develops through a process of geneculture evolution (Sideris 2003). Kahn (1997:11) points out that Kellert and others seem to argue that while evolutionary biology has an important place, "it should not be construed as rigid or deterministic, but rather as setting loose parameters in human lives." Therefore, for example, biophilia suggests that humans may have an innate tendency to spend time tending plants, but this tendency is reinforced culturally through watching and then helping parents and other older, more experienced members of society care for plants.

Proponents of biophilia argue that, rather than referring to a single behavior, biophilia encompasses a broad complex of responses to nature, which include affinities to landscapes and domestic and wild animals, as well as aversions to snakes and cliffs or other high places that pose a threat to humans (Soulé 1993). Kellert (2005) further describes the wide range of values derived from human biophilic dependence (see Fig. 2) and argues that individuals may vary in the types and degree of biophilic responses they express.

Fig. 2. Adapted from Gullone 2000 and Kellert 2005.

$\begin{array}{ll}\text { Kellert's Typology of Values in Nature } \\ \text { Aesthetic } & \text { Physical appeal of and attraction to nature } \\ \text { Dominionistic } & \text { Mastery and control of nature } \\ \text { Humanistic } & \text { Emotional attachment to nature } \\ \text { Moralistic } & \text { Moral and spiritual relation to nature } \\ \text { Naturalistic } & \text { Direct contact with and experience of nature } \\ \text { Negativistic } & \text { Fear of and aversion to nature } \\ \text { Scientific } & \text { Study and empirical observation of nature } \\ \text { Symbolic } & \begin{array}{l}\text { Nature as a source of metaphorical and communicative } \\ \text { thought }\end{array} \\ \text { Utilitarian } & \text { Nature as a source of physical and material benefit }\end{array}$

As briefly mentioned above, the implications for biophilia of Wilson's $(1975,1984)$ broader sociobiological project have been the source of years of debate (Allen et al. 1975, Lewontin et al. 1984, Segerstråle 2000). These debates tend to be over concern about this perspective's implied determinism (Kitcher 1987), and discomfort with its potentially dogmatic tone, especially problematic in gender and racial contexts (Leibowitz 1985). One implication of these concerns is that those mired in urban poverty and cut off from nature may lead a less fulfilling existence, therefore the sociobiological thesis may be accused of cultural and class bias (Kellert and Wilson 1993). Sideris (2003) further notes two additional contradictions inherent in the notion of biophilia; first, that despite their affinity for nature humans readily kill animals ${ }^{[2]}$, and second, that by proposing that humans have averse reactions to dangerous animals such as snakes, biophilia may inadvertently serve as a basis for destroying certain groups of animals rather than for conservation of all biodiversity as originally intended by Wilson (1984).

Despite the furor caused by Wilson and what some deem as implied determinism in his sociobiological thesis (Kitcher 1987), notions of biophilia resurface regularly. Examples of works picking up on or elaborating upon the themes of Wilson's biophilia hypothesis include Kellert and Wilson's edited volume The Biophilia Hypothesis (1993), Lewis's Green Nature/Human Nature (1996), and Kellert's Kinship to Mastery (1997a) and The Value of Life (1997b), as well as his more design-oriented books Biophilic Design (Kellert et al. 2008) and Building for Life (2005). More recently the Meristem Forum released a book entitled Restorative Commons: Creating Health and Well-being through Urban Landscapes (Campbell and Wiesen 2009), which invokes the concept of biophilia frequently in examples of humans restoring landscapes. Other books incorporating the notion of biophilia into design and planning continue to appear, such as Beatley's Biophilic Cities (2010), and Almusaed's Biophilic and Bioclimatic Architecture (2010).

Perhaps most recognizably in the popular press, Richard Louv (2005) introduced the world to the term nature-deficit disorder among children, which refers to the alleged trend that children are spending less time outdoors, resulting in a wide range of behavioral problems. One could argue that nature-deficit disorder is what happens when biophilia is suppressed among people, especially children. When interviewed for the Why Files, an online science magazine, Louv gave credence to the linkage between biophilia and nature-deficit disorder by noting that biologist $\mathrm{E}$. $\mathrm{O}$. Wilson and his colleagues have long talked about the biophilia hypothesis and that even as people are migrating to cities around the world, "We are still huntergatherers biologically." Louv adds, "There is something in us that needs nature. When we don't get it, we don't do so well" (see http://whyfiles.org/shorties/211kid nature/). Whether one agrees or not with Louv and the others listed above, these various manifestations of biophilia since its original inception indicate that some segment of society resonates with claims 
made by Wilson and others that perhaps humans aren't as unique, aren't as special, as we have been led to believe, and that there may be power in that simple realization and in efforts to revisit the assumptions of anthropocentrism.

More than two decades after Wilson proposed biophilia, cell biologists have begun to explore the biological attraction principle (Agnati et al. 2009a), which states that there is an inherent drive for association and merging of compatible elements at all levels of biological complexity (KozoPolyansky 1924/2010, Wallin 1927, Sapp 1994, Baluška et al. 2004a, b, Margulis 2004, Rivera and Lake 2004, Agnati et al. $2009 a, b$, Nicholson 2010, Shapiro 2011). Analogous with the gravitation law in physics, biological attraction posits that each living organism builds an attractive field around itself, and that this field acts as a sphere of influence that actively attracts similar fields of other biological systems, thereby modifying salient features of the interacting organisms. Echoing earlier ideas about biophilia, the biological attraction principle asserts that "the biological 'drive' of attraction is inherent to living and evolving systems and is the result of their inherent biological activities" (Agnati et al. 2009a:554). Further, because it is capable of active modification of some of the salient features of the environment (niche) in which they live, living systems are, therefore, acting on other living organisms, which are sensitive to these features. Importantly, Agnati and colleagues (2009a) argue that sensitivity to this biological attraction seems to increase in biological systems under stress.

The implications for this newer manifestation of biological attraction should be manifestly clear in hazard, disaster, and other contexts characterized by stress. The biological attraction principle as outlined by Agnati and colleagues (2009a) appears to have both explanatory and predictive utility. They argue that it can explain the evolutionary origin of eukaryotic cells, multicellular organisms, and complex ecosystems, and perhaps most salient to this paper's argument, can predict "... a further tightening of bonds in our society, especially when exposed to stress situations" (Agnati et al. 2009a:554).

The work of Agnati and colleagues (2009a) helps us hold on to the essence of Wilson's biophilia, that we are part of nature as demonstrated by our evolutionary traits, while perhaps allowing us to jettison the historical and political baggage that accompanies. A new biophilia, urgent biophilia, rises to provide an explanation for a preponderance of evidence that exists suggesting the restorative effects of seeing and doing green. Do we remember that we are not unique, exempt, or particularly exceptional in the geophysical scheme of things best after being 'flattened' by circumstances beyond our control? What can we learn from this?

\section{FROM BIOPHILIA TO CULTIVATION OF RESILIENCE?}

Fredrickson et al. (2003) hypothesize that resilient people are buffered from depression by positive emotions, and that resilient people thrive through emotions (see also Okvat and Zautra 2012). In a study entitled What Good are Positive Emotions in Crisis? A Prospective Study of Resilience and Emotions Following the Terrorist Attacks on the United States on September 11th, 2001, Fredrickson et al. (2003:374) conclude that: (a) positive emotions do not disappear in times of acute and chronic stress but rather are present and functional during crisis, and (b), that:

efforts to cultivate and nurture positive emotions in the aftermath of crisis pay off both in the short-term, by improving subjective experiences, undoing physiological arousal, and enhancing broadminded coping, and in the long-term, by minimizing depression and building enduring resources, the hallmark of thriving.

They further suggest that "finding positive meaning may be the most powerful leverage point for cultivating positive emotions during times of crisis" (Fredrickson et al. 2003:374).

The use of the word cultivation in the passages above is appropriate at two levels, both explicit and metaphorical. The metaphoric level, and its nod toward urgent biophilia, which I link to both the creation of and benefit from restorative environments, appears more clearly with further study of the word's many meanings. Cultivation has its roots in the transitive verb 'cultivate' (see http://education.yahoo.com/ref erence/dictionary/entry/cultivate; ylt=Al3kDE0jJEFvFFovLH dfB2CsgMMF) which is defined as:

1. a. To improve and prepare (land), as by plowing or fertilizing, for raising crops; to till.

b. To loosen or dig soil around (growing plants).

2. To grow or tend (a plant or crop).

3. To promote the growth of (a biological culture).

4. To nurture; foster.

5. To form and refine, as by education.

6. To seek the acquaintance or goodwill of; make friends with.

Keeping in mind these definitions of cultivation, and recognizing their relationship to Kellert's typology (Fig. 2), it is intriguing to contemplate aspects of cultivation within the literature on positive emotions and nature. In a study of positive emotions in residential environments in postwar settlements in Germany, Graff (2006) found a strong positive response to greenery, confirming yet again the work of Ulrich, Kaplan, and others. Similarly, evolutionary psychologist Haviland-Jones and others (2005) have used language 
reminiscent of systems thinking's use of feedbacks and virtuous cycles (Weinstein and Tidball 2007, Tidball and Krasny 2011, Tidball and Weinstein 2011), which are often important features of resilient systems, to describe the relationship between humans cultivating plants and cultivating positive emotions:

(C) ultivated flowers fit into an emotional niche their sensory properties elicit human positive emotions. The flowering plants are thereby rewarding to humans and in return, the cultivated flowers receive propagation that only humans can provide. Demonstration of such a phenomenon fills several gaps in the literature. It supports the basic significance of emotion for survival. As a corollary it supports the adaptive function of positive as well as negative emotion...and opens an area of investigation into the psychological relationships between humans and other species through their sensory properties that have been relatively neglected. (Haviland-Jones et al. 2005:127)

Lohr and Pearson-Mims (2006) similarly report that people experience more positive emotions, such as friendliness, and fewer negative emotions, such as sadness, when they are looking at urban scenes with trees than when looking at the same scenes containing inanimate objects. Several other studies have pointed to the value individuals, as well as communities, place on trees and other aspects of nature immediately after a disaster, alluding to notions of cultivation's characteristics of nurturing and protection. An example can be found in Hull's work in which he identified urban forests as the most significant feature that was damaged by a hurricane, despite the fact that there was significant damage to buildings (Hull 1992). According to residents, of the numerous values associated with the urban forest postHugo, positive emotions evoked by trees were most important, followed by the importance of trees in defining Charleston as a community or place. According to Hull (1992:100), "the role of urban forests as symbols of cherished meanings and memories needs to be emphasized as a major benefit deriving from urban forestry ... Trees symbolize spiritual values, personal memories, reminders of the past, preservation and endurance." This cultivation of trees as important symbolically as well as functionally is dealt with in greater depth in my work in post-Katrina New Orleans (see Tidball and Krasny 2008, Tidball 2012; K. G. Tidball, unpublished manuscript, http://www.aaanet.org/mtgs/search/viewDetail.cfm? itemtype $=$ paper poster \&matchid=18154).

\section{LINKS BETWEEN URGENT BIOPHILIA AND RESILIENCE}

This contribution has as one of its aims the examination of the linkages between urgent biophilia and resilience from individual, through family, neighborhood, community, and larger spatial and temporal scales in hazard, disaster, and vulnerability contexts. Urgent biophilia, or the idea that human-nature interactions and the positive emotions they elicit can rapidly and unexpectedly play an important role in conferring resilience across scales in postdisaster contexts, will undoubtedly be met with resistance, given such other equally urgent needs as personal safety and security, food, water, medical supplies, and rebuilding functional infrastructure. Despite this, and referring to resilience scholars Walker and colleagues (2002), understanding where resilience resides in the system, and when and how it can be lost or gained, is required to manage a system for resilience.

Here I hypothesize that one source of SES resilience after a disaster is humans' affinity for nature and the urge to express that affinity through creation of restorative environments, which may also restore ecological function. In other words, resilience in a red zone system may reside in places like memories of the value of interacting with plants (Tidball al. 2010) or other life forms, in the act of expressing urgent biophilia as argued here, or in the planted, restored spaces themselves. I suspect that resilience in red zone systems likely resides in a combination of all of these. As it relates to the adaptive cycle (Holling and Gunderson 2002) it would appear that the contribution of urgent biophilia to SES resilience resides or flourishes in the 'back loop,' the time of greatest potential for the initiation of change in the system (Walker and Salt 2006; see also Fig. 1). In this vein, I propose revisiting Folke et al.'s (2002:51) statement that "erosion of the sources of resilience leads to fragile social-ecological systems, with consequences for human livelihoods, vulnerability, security, and conflicts [emphasis added]." Instead, tailoring the Folke et al. statement as a way of understanding urgent biophilia as a source of resilience, I posit that: cultivation of the sources of resilience may lead to vital social-ecological systems, with positive implications for human livelihoods, vulnerability, security, and conflicts. Greening in the red zone, then, can be imagined as a manifestation of a conscious, urgent biophilia acting as and activating a source of resilience in postconflict and postdisaster settings.

\section{CONCLUSION}

In summary, integrating Wilson's (1984) notions of biophilia with more recent research on positive responses to plants and green spaces including in postdisaster settings, I have proposed the following explanation for an urgent biophilia. During more stable periods, humans exhibit varying degrees of affinity for nature at what Wilson and others argue is a mostly subconscious level. We often use forms of nature stewardship to recover from personal hardship. However, in postdisaster contexts, so-called human-nature interactions and the positive emotions they elicit may compellingly and suddenly come to the fore in heretofore unexpected ways, and be manifested in immediate and conscious actions, often beyond merely individuals to include neighborhoods, 
communities, and whole societies (see Fig. 1). Urgent biophilia then is a highly sensitized manifestation of biological attraction whereby living organisms, including humans, build or utilize attractive fields around themselves, and that these fields act as a sphere of influence that actively attract similar fields of other biological systems, thereby modifying salient features of the interacting organisms (Agnati et al. 2009a).

Further, such manifestations of affinity for nature after a disaster, urgent biophilia, may play a critical role in the ability of humans and larger social-ecological systems to recover postdisaster. This switch from baseline subconscious biophilia or biological attraction during times of growth and stability, to conscious urgent biophilia during times of collapse followed by reorganization reflects cyclic changes described as the adaptive cycle in SES resilience writings (cf. Gunderson and Holling 2002). Once war, hurricanes, earthquakes, tsunamis, or another disaster threaten to 'flip' a SES into a less desirable state, humans may respond to feeling threatened or a sense of loss by seeking physical and emotional affiliation with other living organisms, and in so doing, may aid themselves, as well as other parts of the system, in recovery. Should this urgent biophilic response also include individuals working collectively to enhance their local environment, e.g., through community forestry and community gardening, it may further contribute to recovery of other ecological elements of the larger SES. Although this urgent response does not necessarily take us in the direction that Wilson and others envisioned when proposing biophilia, i.e., furthering the claims of sociobiology or conservation of biodiversity, it may have implications for better understanding human-nature interactions in SES experiencing hazard, disaster, or vulnerability, and the relationship those human-nature interactions have to SES resilience.

Thus far the evidence for urgent biophilia as a possible explanation for the myriad examples of greening in hazard, disaster, and vulnerability contexts (Tidball and Krasny 2012a) comes from synthesizing on-the-ground examples with research about human-nature relations and socialecological systems resilience. Because research that focuses specifically on greening responses in hazard, disaster, and vulnerability contexts is hard to come by, this paper is meant to stimulate thinking about possibilities, about the potential for greening to help people reorganize and rebuild after surprise or rapid change. Such thinking will inevitably raise questions that could be answered by interdisciplinary research drawing from the social and ecological sciences.

For example, in the area of human-nature relations, much work has been done on the emotional, psychological, and cognitive impacts of exposure to green spaces among hospital patients, young children, and residents of low income housing, and a few studies have been conducted on the outcomes of active engagement in greening among urban greening participants.
However, we currently lack empirical research, such as longterm, comparative, or other studies, that more rigorously tests the impacts of greening specifically on individuals and communities in hazard, disaster, and vulnerability contexts.

Relative to social-ecological systems resilience, many studies have described social and ecological processes within particular systems, for example fishing dependent villages in Southeast Asia (Daw et al. 2009), First Nations communities in the boreal region of Canada (Berkes et al. 2000), and forest dependent communities in the Pacific Northwest (FernandezGimenez et al. 2008). Other authors have described rebuilding processes postdisaster (Vale and Campanella 2005) or have distilled characteristics of disasters, including frequency, magnitude, and extent, that can be used as a basis for planning interventions (Pelling 2003). However, to date there are few if any empirical studies that use a social-ecological systems framework to study processes occurring in disaster and conflict zones, and that treat these zones as a type of emergent and relatively short-lived social-ecological system with a unique set of characteristics different from those of other systems. Do disaster and conflict zone systems share commonalities relative to social and ecological processes that cut across specific contexts?

A fundamental issue for future research around these questions is how researchers might partner with on-the-ground implementers and policy makers in defining research questions, collecting data, and other aspects of the research process. When policy makers, project implementers, and community leaders working in hazard, disaster, and vulnerability contexts are involved in research, questions may be better informed by real-life experience and needs, and the results may be more readily reinserted into policies and onthe-ground practices.

Many difficulties face a researcher investigating urgent biophilia and the role of greening in hazard, disaster, and vulnerability contexts. Given the dangerous and challenging conditions that characterize these contexts and the oftentimes spontaneous responses, controlled experiments will likely be impossible. Instead 'natural' experiments looking at variations in conditions that occur in the field, or qualitative research that follows urgent biophilia and resulting greening practices indepth and over time, may be employed. In addition, commonly held notions about linear relationships may not hold. For example, the ability of a community to mount a greening or other response to disaster depends in part on existing human capital, yet at the same time when a community is able to take charge and respond effectively to a disaster, human capital may be created. The same may be true for social, cultural, and natural capital, as well as for sense of place. Further complicating any research endeavor, these different capitals interact with each other through greening, as when a group of individuals with trusting relationships and a history of 
volunteerism (aspects of social capital) is able to come together to recreate natural capital lost in a disaster, e.g., by planting trees. These relationships may be envisioned as the different forms of capital nested within each other in a progressively larger series of concentric rings, from human to social to ecological (cf. Wimberley 2009). Alternatively, processes at the individual, social-cultural, and ecological scale may be viewed as nested adaptive cycles forming panarchies of smallscale, relatively fast processes both impacting and being impacted by larger and slower processes (cf. Gunderson and Holling 2002). To add to the research challenges, multiple forms of capital that are integrated in a greening response serve as both sources and expressions of resilience during disaster as well as during the rebuilding period.

Despite these challenges to researching in greater depth urgent biophilia and greening, the fact remains that an understanding of the importance of human-nature interactions at the point when social-ecological systems are experiencing upheaval and the humans within them experiencing great vulnerability is of critical importance (Vining et al. 2008). Such an understanding of human-nature interaction in terms of resilience can only help when disaster or war strikes, and it is my hope that future research into urgent biophilia as it is manifested in greening in hazard, disaster, or vulnerability contexts will contribute to efforts by governments, NGOs, and others to adapt, reorganize, and rebuild in the aftermath of crisis.

${ }^{[1]}$ For an overview of green political thought, see http://www. greenparty.org/ and http://www.globalgreens.org/globalcharterenglish.

[2] The author does not believe that killing animals must necessarily indicate less affinity for life or nature; see Tantillo, J. 2001. Sport hunting, eudaimonia, and tragic wisdom. Philosophy in the Contemporary World 8(2):101-112.

Responses to this article can be read online at: http://www.ecologyandsociety.org/voll7/iss2/art5/responses/

\section{Acknowledgments:}

I am grateful to Marianne Krasny for many critical discussions about Wilson's biophilia and its explanatory utility in discussions about community greening in a general sense, as well as for multiple helpful reviews of earlier versions of this contribution. I also acknowledge the useful conversations and insightful historical perspectives contributed by James Tantillo and Richard Stedman on biophilia and the debates around sociobiology. I wish to express my gratitude to Lance Gunderson for his thorough and insightful review of early versions of this manuscript and to Stephen Kellert for his elaboration of the biophilia hypothesis and for his invaluable review of this contribution. I am grateful to those who provided helpful feedback when an earlier version of this contribution was presented at the Resilience 2011 conference in Tempe, Arizona, especially Henrik Ernstson, Stephan Barthel, and Joshua Lewis. I thank all of the above-mentioned, two anonymous reviewers, and acknowledge that any errors of omission or commission are only my own.

\section{LITERATURE CITED}

Adger, W. N., T. P. Hughes, C. Folke, S. R. Carpenter, and J. Rockström. 2005. Social-ecological resilience to coastal disasters. Science 309(5737):1036-1039. http://dx.doi.org/10 $.1126 /$ science. 1112122

Agnati, L., F. Baluska, P. W. Barlow, and D. Guidolin. $2009 a$. Mosaic, self-similarity logic, and biological attraction principles: three explanatory instruments in biology. Communicative and Integrative Biology 2(6):552-563. http:// dx.doi.org/10.4161/cib.2.6.9644

Agnati, L., K. Fuxe, F. Baluška, and D. Guidolin. 2009 b. Implications of the 'Energide' concept for communication and information handling in the central nervous system. Journal of Neural Transmission 116:1037-1052. http://dx.doi.org/10.1 007/s00702-009-0193-1

Allen, E., B. Beckwith, J. Beckwith, S. Chorover, D. Culver, M. Duncan, S. Gould, R. Hubbard, H. Inouye, A. Leeds, R. Lewontin, C. Madansky, L. Miller, R. Pyeritz, M. Rosenthal, and H. Schreier. 1975. Against "sociobiology." New York Review of Books 182:184-186.

Almusaed, A. 2010. Biophilic and bioclimatic architecture: analytical therapy for the next generation of passive sustainable architecture. Springer-Verlag, London, UK.

Austin, M. E., and R. Kaplan. 2003. Identity, involvement, and expertise in the inner city: some benefits of tree-planting projects. Pages 205-225 in S. Clayton and S. Opotow, editors. Identity and the natural environment: the psychological significance of nature. MIT Press, Cambridge, Massachusetts, USA.

Baluška, F., D. Volkmann, and P. W. Barlow. 2004a. Cell bodies in a cage. Nature 428:371. http://dx.doi.org/10.1038/4 $28371 \mathrm{a}$

Baluška, F., D. Volkmann, and P. W. Barlow. $2004 b$. Eukaryotic cells and their cell bodies: cell theory revised. Annals of Botany 94:9-32. http://dx.doi.org/10.1093/aob/mch109

Barthel, S., J. Colding, T. Elmqvist, and C. Folke. 2005. History and local management of a biodiversity-rich, urban cultural landscape. Ecology and Society 10(2): 10. http://www .ecologyandsociety.org/vol10/iss2/art10/

Barthel, S., J. Parker, C. Folke, and J. Colding 2012. Urban gardens - pockets of social-ecological memory. In K. G. Tidball and M. E. Krasny, editors. Greening in the red zone: 
disaster, resilience, and community greening. Springer, New York, New York, USA.

Beatley, T. 2010. Biophilic cities: integrating nature into urban design and planning. Island Press, Washington, D.C., USA.

Bell, S., V. Hamilton, A. Montarzino, H. Rothnie, P. Travlou, and S. Alves. 2008. Greenspace and quality of life: a critical literature review. Greenspace Scotland, Stirling, UK.

Berger, R., and J. McLeod. 2006. Incorporating nature into therapy: a framework for practice. Journal of Systematic Therapies 25(2):80-94. http://dx.doi.org/10.1521/jsyt.2006.25.2.80

Berkes, F., J. Colding, and C. Folke. 2000. Rediscovery of traditional ecological knowledge as adaptive management. Ecological Applications 10:1251-1262. http://dx.doi.org/10.1 890/1051-0761(2000)010[1251:ROTEKA]2.0.CO;2

Berkes, F., J. Colding, and C. Folke. 2003. Navigating socialecological systems: building resilience for complexity and change. Cambridge University Press, Cambridge, UK.

Berlyne, D. E. 1960. Conflict, arousal, and curiosity. McGraw-Hill, New York, New York, USA. http://dx.doi.org /10.1037/11164-000

Betrabet, G. 1996. The garden as a restorative environment: a theoretical perspective. Journal of Therapeutic Horticulture 8:15-20.

Blaikie, P., T. Cannon, I. Davis, and B. Wisner. 2003. At risk: natural hazards, people's vulnerability, and disasters. Routledge, London, UK.

Branas, C. C., R. A. Cheney, J. M. MacDonald, V. W. Tam, T. D. Jackson, and T. R. Ten Have. 2011. A difference-indifferences analysis of health, safety, and greening vacant urban space. American Journal of Epidemiology 171 (11):1296-1306. http://dx.doi.org/10.1093/aje/kwr273

Brdanovic, D. 2009. Gardens for peace and reconciliation. Pages 248-263 in L. Campbell and A. Wiesen, editors. Restorative commons: creating health and well-being through urban landscapes. General Technical Report NRS-P-39, U.S. Forest Service, Newtown Square, Pennsylvania, USA.

Brett, S., L. Bickford, L. Sevenko, and M. Rios. 2007. Memorialization and democracy: state policy and civic action. International Center for Transitional Justice, New York, New York, USA.

Campbell, L., and A. Wiesen, editors. 2009. Restorative commons: creating health and well-being through urban landscapes. General Technical Report NRS-P-39, U.S. Forest Service, Newtown Square, Pennsylvania, USA.
Cheng, S., and J. R. McBride. 2006. Restoration of the urban forests of Tokyo and Hiroshima following World War II. Urban Forestry \& Urban Greening 5(4):155-168. http://dx.d oi.org/10.1016/j.ufug.2006.07.003

Cimprich, B. 1993. Development of an intervention to restore attention in cancer patients. Cancer Nursing 16:83-92. http:// dx.doi.org/10.1097/00002820-199304000-00001

Cooper Marcus, C., and M. Barnes. 1999. Healing gardens: therapeutic benefits and design recommendations. John Wiley $\&$ Sons, New York, New York, USA.

Daniels, R. J., D. J. Kettl, and H. Kunreuther, editors. 2006. On risk and disaster: lessons from Hurricane Katrina. University of Pennsylvania Press, Philadelphia, Pennsylvania, USA.

Davidson-Hunt, I., and F. Berkes. 2003. Learning as you journey: Anishinaabe perception of social-ecological environments and adaptive learning. Conservation Ecology 8 (1): 5. [online] URL: http://www.consecol.org/vol8/iss1/art5/

Daw, T., W. N. Adger, K. Brown, and M.-C. Badjeck. 2009. Climate change and capture fisheries: potential impacts, adaptation, and mitigation. Pages 107-150 in K. Cochrane, C. De Young, D. Soto, and T. Bahri, editors. Climate change implications for fisheries and aquaculture: overview of current scientific knowledge. FAO Fisheries and Aquaculture Technical Paper Number 530, Food and Agriculture Organization, Rome, Italy.

Diamond, J. 2005. Collapse: how societies choose to fail or succeed. Viking, New York, New York, USA.

Downing, A. J. 1869. A talk about public parks and gardens. Pages 138-146 in G. W. Curtis, editor. Rural Essays by A. J. Downing. Leavitt \& Allen, New York, New York, USA.

Drennan, M. P. 2007. The economic cost of disasterspermanent or ephemeral? Pages 159-191 in P. Gordon and H. Richardson, editors. Economic costs and consequences of terrorism. Edward Elgar, Cheltenham, UK.

Driver, B. L., and R. C. Knopf. 1976. Temporary escape: one product of sport fisheries management. Fisheries 1:24-29.

Dunlap, R. E. 1980. Paradigmatic change in social science: from human exemptions to an ecological paradigm. American Behavioral Scientist 24(1):5-14. http://dx.doi.org/10.1177/00 $\underline{0276428002400102}$

Dunlap, R. E., and W. R. Catton, Jr. 1994. Struggling with human exemptionalism: the rise, decline and revitalization of environmental sociology. American Sociologist 25(1):5-30. http://dx.doi.org/10.1007/BF02691936

Elings, M. 2006. People-plant interaction: the physiological, psychological and sociological effects of plants on people. 
Pages 43-55 in J. Hassink and M. v. Dijk, editors. Farming for health: green-care farming across Europe and the United States of America. Springer, Dordrecht, The Netherlands. htt p://dx.doi.org/10.1007/1-4020-4541-7_4

Ernstson, H., S. Sörlin, and T. Elmqvist. 2008. Social movements and ecosystem services-the role of social network structure in protecting and managing urban green areas in Stockholm. Ecology and Society 13(2): 39. [online] URL: http://www.ecologyandsociety.org/vol13/iss2/art39/

Faber Taylor, A., A. Wiley, F. E. Kuo, and W. C. Sullivan. 1998. Growing up in the inner city: green spaces as places to grow. Environment and Behavior 30(1):3-27. http://dx.doi.or $\mathrm{g} / 10.1177 / 0013916598301001$

Fernandez-Gimenez, M. E., H. L. Ballard, and V. E. Sturtevant. 2008. Adaptive management and social learning in collaborative and community-based monitoring: a study of five community-based forestry organizations in the western USA. Ecology and Society 13(2): 4. [online] URL: http://ww w.ecologyandsociety.org/vol13/iss2/art4/

Folke, C., S. Carpenter, T. Elmqvist, L. Gunderson, C. S. Holling, and B. Walker. 2002. Resilience and sustainable development: building adaptive capacity in a world of transformations. Ambio 31(5):437-440. http://dx.doi.org/10.1 $\underline{579 / 0044-7447-31.5 .437}$

Fox, S. R. 1981. John Muir and his legacy: the American conservation movement. Little, Brown, Boston, Massachusetts, USA.

Fredrickson, B. L., M. M. Tugade, C. Waugh, and G. R. Larkin. 2003. What good are positive emotions in crisis? A prospective study of resilience and emotions following the terrorist attacks on the United States on September 11th, 2001. Journal of Personality and Social Psychology 84(2):365-376. http://dx.d oi.org/10.1037//0022-3514.84.2.365

Fromm, E. 1964. The heart of man. Harper \& Row, New York, New York, USA.

Frumkin, H. 2001. Beyond toxicity: human health and the natural environment. American Journal of Preventive Medicine 20(3):234-240. http://dx.doi.org/10.1016/S0749-3797 (00)00317-2

Ganyard, S. T. 2009. All disasters are local. New York Times, 17 May.

Gibbs, M. T. 2009. Resilience: what is it and what does it mean for marine policymakers? Marine Policy 33(2):322-331. http ://dx.doi.org/10.1016/j.marpol.2008.08.001

Graff, B. 2006. Positive emotions in residential environments. Proceedings of The Residential Context of Health at the European Network for Housing Research's Housing in an Expanding Europe: Theory, Policy, Participation and Implementation Conference. Ljubljana, Slovenia.
Granovetter, M. 1973. The strength of weak ties. American Journal of Sociology 78(6):1360-1380. http://dx.doi.org/10.1 $\underline{086 / 225469}$

Gullone, E. 2000. The biophilia hypothesis and life in the 21st century: increasing mental health or increasing pathology? Journal of Happiness Studies 1(3):293-322. http://dx.doi.org/ 10.1023/A:1010043827986

Gunderson, L. H., and C. S. Holling, editors. 2002. Panarchy: understanding transformations in human and natural systems. Island Press, Washington, D.C., USA.

Hartig, T. 2007. Toward understanding the restorative environment as a health resource. Open Space: People Space 2 Conference. Edinburgh, Scotland.

Hartig, T., M. Mang, and G. W. Evans. 1991. Restorative effects of natural environment experiences. Environment and Behavior 23(1):3-26. http://dx.doi.org/10.1177/0013916591231001

Hartig, T., and H. Staats. 2003. Guest editors' introduction: restorative environments. Journal of Environmental Psychology 23(2):103-107. http://dx.doi.org/10.1016/S0272-4944 (02)00108-1

Hartig, T., and H. Staats. 2006. The need for psychological restoration as a determinant of environmental preferences. Journal of Environmental Psychology 26(3):215-226. http://d x.doi.org/10.1016/j.jenvp.2006.07.007

Haviland-Jones, J., H. Rosario, P. Wilson, and T. R. McGuire. 2005. An environmental approach to positive emotion: flowers. Evolutionary Psychology 3:104-132.

Helphand, K. 2006. Defiant gardens: making gardens in wartime. Trinity University Press, San Antonio, Texas, USA.

Helphand, K. 2012. Reflections on defiant gardens: making gardens in wartime. In K. G. Tidball and M. E. Krasny, editors. Greening in the red zone: disaster, resilience, and community greening. Springer, New York, New York, USA.

Herzog, T. R., and J. A. Flynn-Smith. 2001. Preference and perceived danger as a function of the perceived curvature, length, and width of urban alleys. Environment and Behavior 33:653-666. http://dx.doi.org/10.1177/00139160121973179

Hewson, M. 2001. Horticultural therapy and post traumatic stress recovery. Journal of Therapeutic Horticulture 12.

Hoffman, S. M., and A. Oliver-Smith, editors. 2002. Catastrophe and culture: the anthropology of disaster. James Curry, Oxford, UK.

Holling, C. S., and L. Gunderson. 2002. Resilience and adaptive cycles. Pages 25-62 in L. Gunderson and C. S. Holling, editors. Panarchy: understanding transformations in 
human and natural systems. Island Press, Washington, D.C., USA.

Hull, R. B. 1992. How the public values urban forests. Journal of Arboriculture 18(2):98-101.

International Federation of Red Cross and Red Crescent Societies (IFRC). 2004. World disasters report, 2004: focus on community resilience. Kumarian Press, Bloomfield, Connecticut, USA.

Inter-Agency Standing Committee. 2007. IASC guidelines on mental health and psychosocial support in emergency settings. IASC, Geneva, Switzerland.

Kahn, J. P. H. 1999. The human relationship with nature. MIT Press, Cambridge, Massachusetts, USA.

Kahn, P. H. 1997. Developmental psychology and the biophilia hypothesis: children's affiliation with nature. Developmental Review 17(1):1-61. http://dx.doi.org/10.1006/ drev.1996.0430

Kaplan, R., and S. Kaplan. 1989. The experience of nature: a psychological perspective. Cambridge University Press, Cambridge, UK.

Kaplan, S. 1995. The restorative benefits of nature: towards an integrative framework. Journal of Environmental Psychology 15:169-182. http://dx.doi.org/10.1016/0272-4944 (95)90001-2

Kaplan, S., and J. F. Talbot. 1983. Psychological benefits of a wilderness experience. Pages 163-203 in I. Altman and J. F. Wohlwill, editors. Behavior and the natural environment. Plenum Press, New York, New York, USA.

Kellert, S. R. 1993. Introduction. Pages 20-28 in S. R. Kellert and E. O. Wilson, editors. The biophilia hypothesis. Island Press, Washington, D.C., USA.

Kellert, S. R. 1997a. Kinship to mastery: biophilia in human evolution and development. Island Press, Washington, D.C., USA.

Kellert, S. R. 1997b. The value of life: biological diversity and human society. Island Press, Washington, D.C., USA.

Kellert, S. R. 2005. Building for life: designing and understanding the human-nature connection. Island Press, Washington, D.C., USA.

Kellert, S. R., J. H. Heerwagen, and M. L. Mador, editors. 2008. Biophilic design: the theory, science and practice of bringing buildings to life. John Wiley \& Sons, Hoboken, New Jersey, USA.

Kellert, S. R., and E. O. Wilson, editors. 1993. The biophilia hypothesis. Island Press, Washington, D.C., USA.

Ke-Tsung, H. 2001. A review: theories of restorative environments. Journal of Therapeutic Horticulture 12.
King, A. C., D. Stokols, E. Talen, G. S. Brassington, and R. Killingsworth. 2002. Theoretical approaches to the promotion of physical activity: forging a transdisciplinary paradigm. American Journal of Preventive Medicine 23(2S):15-25. http ://dx.doi.org/10.1016/S0749-3797(02)00470-1

Kitcher, P. 1987. Vaulting ambition: sociobiology and the quest for human nature. MIT Press, Cambridge, Massachusetts, USA.

Kozo-Polyansky, B. 2010. Symbiogenesis: a new principle of evolution. Harvard University Press, Cambridge, Massachusetts, USA. (Original work published 1924)

Krasny, M. E., K. Pace, K. G. Tidball, and K. Helphand. 2012. Nature engagement to foster resilience in military communities. In K. G. Tidball and M. E. Krasny, editors. Greening in the red zone: disaster, resilience, and community greening. Springer, New York, New York, USA.

Krasny, M. E., and K. G. Tidball. 2010. Civic ecology: linking social and ecological approaches in extension. Journal of Extension 48(1):1IAW1.

Krasny, M. E., and K. G. Tidball. 2012. Civic ecology: a pathway for Earth stewardship in cities. Frontiers in Ecology and the Environment.

Kuo, F. E., M. Bacaicoa, and W. C. Sullivan. 1998. Transforming inner-city landscapes: trees, sense of safety, and preference. Environment and Behavior 30:28-59. http://dx.doi. org/10.1177/0013916598301002

Kuo, F. E., and W. C. Sullivan 2001. Environment and crime in the inner city: does vegetation reduce crime? Environment and Behavior 33:343-367. http://dx.doi.org/10.1177/0013916 $\underline{501333002}$

Kurakin, A. 2009. Scale-free flow of life: on the biology, economics, and physics of the cell. Theoretical Biology and Medical Modelling 6(6). http://dx.doi.org/10.1186/1742-4682-6-6

Leibowitz, L. 1985. Humans and other animals: a perspective on perspectives. Dialectical Anthropology 9(1-4):127-142. http://dx.doi.org/10.1007/BF00245126

Lewis, C. 1996. Green nature/human nature. University of Illinois Press, Chicago, Illinois, USA.

Lewis, C. A., and S. Sturgill. 1979. Comment: healing in the urban environment: a person/plant viewpoint. Journal of the American Planning Association 45(3):330-338. http://dx.doi. org/10.1080/01944367908976971

Lewontin, R. C., S. P. R. Rose, and L. J. Kamin. 1984. Not in our genes: biology, ideology, and human nature. Pantheon, New York, New York, USA. 
Light, A. 2003. Urban ecological citizenship. Journal of Social Philosophy 34(1):44-63. http://dx.doi.org/10.1111/1467-9833 .00164

Lindemuth, A. L. 2012. Beyond the bars: landscapes for health and healing in corrections. In K. G. Tidball and M. E. Krasny, editors. Greening in the red zone: disaster, resilience, and community greening. Springer, New York, New York, USA.

Lohr, V. I., and C. H. Pearson-Mims. 2006. Responses to scenes with spreading, rounded, and conical tree forms. Environment and Behavior 38(5):667-688. http://dx.doi.org/1 $\underline{0.1177 / 0013916506287355}$

Longstaff, P. H. 2005. Security, resilience, and communication in unpredictable environments such as terrorism, natural disasters, and complex technology. Harvard University Program on Information Resources Policy, Cambridge, Massachusetts, USA.

Louv, R. 2005. Last child in the woods: saving our children from nature-deficit disorder. Algonquin Books, Chaple Hill, North Carolina, USA.

Maas, J., P. Spreeuwenberg, M. Van Winsum-Westra, R. A. Verheij, S. de Vries, and P. P. Groenewehen. 2009. Is green space in the living environment associated with people's feelings of social safety? Environment and Planning 41 (7):1763-1777. http://dx.doi.org/10.1068/a4196

Margulis, L. 2004. Serial endosymbiotic theory (SET) and composite individuality. Transition from bacterial to eukaryotic genomes. Microbiology Today 31:172-174.

Markee, K. M., and J. Janick. 1979. A bibliography for horticultural therapy (1970-1978): comparison of literature search techniques in an interdisciplinary field. Horticulture Science 6:692-696.

Masten, A. S., K. M. Best, and N. Garmezy. 1990. Resilience and development: contributions from the study of children who overcome adversity. Development and Psychopathology 2(04):425-444. http://dx.doi.org/10.1017/S0954579400005812

Masten, A. S., and J. Obradović. 2008. Disaster preparation and recovery: lessons from research on resilience in human development. Ecology and Society 13(1): 9. [online] URL: http://www.ecologyandsociety.org/vol13/iss1/art9/

Mazel, D. 2000. American literary environmentalism. University of Georgia Press, Athens, Georgia, USA.

McLuhan, T. 1994. The way of the earth: encounters with nature in ancient and contemporary thought. Simon \& Schuster, New York, New York, USA.

Miavitz, E. M. 1998. Grief gardening. Journal of Therapeutic Horticulture 9.
Milani, B. 2000. Designing the green economy: the postindustrial alternative to corporate globalization. Rowman and Littlefield Publishers, Lanham, Maryland, USA.

Miles, I., W. C. Sullivan, and F. E. Kuo. 1998. Ecological restoration volunteers: the benefits of participation. Urban Ecosystems 2:27-41. http://dx.doi.org/10.1023/A:1009501515335

Miller, F., H. Osbahr, E. Boyd, F. Thomalla, S. Bharwani, G. Ziervogel, B. Walker, J. Birkmann, S. Van der Leeuw, J. Rockström, J. Hinkel, T. Downing, C. Folke, and D. Nelson. 2010. Resilience and vulnerability: complementary or conflicting concepts? Ecology and Society 15(3): 11. [online] URL: http://www.ecologyandsociety.org/vol15/iss3/art11/

Moore, E. A. 2012. Refugee camp reforestation and reconciliation. In K. G. Tidball and M. E. Krasny, editors. Greening in the red zone: disaster, resilience, and community greening. Springer, New York, New York, USA.

Murphy, P. D., T. Gifford, and K. Yamazato. 1998. Literature of nature: an international sourcebook. Fitzroy Dearborn, Chicago, Illinois, USA.

Nash, R. 1982. Wilderness and the American mind. Yale University Press, New Haven, Connecticut, USA.

Nicholson, D. 2010. Biological atomism and cell theory. Studies in History and Philosophy of Biological and Biomedical Sciences 41:202-211. http://dx.doi.org/10.1016/j. shpsc.2010.07.009

Okvat, H. A., and A. J. Zautra. 2012. Sowing seeds of resilience: community gardening in a post-disaster context. In K. G. Tidball and M. E. Krasny, editors. Greening in the red zone: disaster, resilience, and community greening. Springer, New York, New York, USA.

Oliver-Smith, A. 2002. Theorizing disasters: nature, power, and culture. Pages 23-48 in S. M. Hoffman and A. OliverSmith, editors. Catastrophe and culture: the anthropology of disaster. School of American Research Press, Santa Fe, New Mexico, USA.

Oliver-Smith, A., and S. M. Hoffman 2002. Introduction: why anthropologists should study disasters. Pages 3-22 in S. M. Hoffman and A. Oliver-Smith, editors. Catastrophe and culture: the anthropology of disaster. School of American Research Press, Santa Fe, New Mexico, USA.

Olmsted, F. L. 1865/1952. The Yosemite Valley and the Mariposa big trees: a preliminary report: with an introductory note by Laura Wood Roper. Landscape Architecture 43:12-25.

Peacock, W. G., B. H. Morrow, and H. Gladwin. 1997. Hurricane Andrew: ethnicity, gender and the sociology of disasters. Routledge, New York, New York, USA. 
Pearce, D. W., A. Markandya, and E. B. Barbier. 1992. Blueprint for a green economy. Earthscan, London, UK.

Pelling, M. 2003. The vulnerability of cities: natural disasters and social resilience. Earthscan, London, UK.

Reece Hardy, S., S. Goddard, and L. Krishtalka. 2009. Among trees. Trees and other ramifications: branches in nature and culture. Spencer Museum of Art, University of Kansas, Lawrence, Kansas, USA.

Reilly, B. 2009. Disaster and human history: case studies in nature, society, and catastrophe. McFarland and Company, Jefferson, North Carolina, USA.

Relf, D. 1992. The role of horticulture in human well-being and social development. Timber Press, Portland, Oregon, USA.

Relf, D. 2005. The therapeutic values of plants. Developmental Neurorehabilitation 8(3):235-237. http://dx.doi.org/10.1080/1 $\underline{3638490400011140}$

Relf, D., and S. Dorn. 1995. Horticulture: meeting the needs of special populations. Horticulture Technology 2:94-104.

Relf, P. D. 2006. Agriculture and health care: the care of plants and animals for therapy and rehabilitation in the United States. Pages 309-343 in J. Hassink and M. v. Dijk, editors. Farming for health: green-care farming across Europe and the United States of America. Springer, Dordrecht, The Netherlands.

Riley, R. B. 1992. Flowers, power and sex. Pages 60-75 in M. Francis and Randolph T. Hester, Jr., editors. The meaning of gardens. MIT Press, Cambridge, Massachusetts, USA.

Rivera, M., and J. Lake. 2004. The ring of life provides evidence for a genome fusion origin of eukaryotes. Nature 431:152-155. http://dx.doi.org/10.1038/nature02848

Ryan, R. L., and R. E. Grese. 2005. Urban volunteers and the environment: forest and prairie restoration. Pages 173-188 in P. F. Barlett, editor. Urban place: reconnecting with the natural world. MIT Press, Cambridge, Massachusetts, USA.

Saldivar-Tanaka, L., and M. E. Krasny. 2004. Culturing community development, neighborhood open space, and civic agriculture: the case of Latino community gardens in New York City. Agriculture and Human Values 21:399-412. http:// dx.doi.org/10.1023/B:AHUM.0000047207.57128.a5

Salick, J. 1995. Toward an integration of evolutionary ecology and economic botany: personal perspectives on plant/people interactions. Annals of the Missouri Botanical Garden 82 (1):25-33. http://dx.doi.org/10.2307/2399977

Sapp, J. 1994. Evolution by association: a history of symbiosis. Oxford University Press, Oxford, UK.

Sattler, D. N., J. F. Freedy, K. Anderson, and C. F. Kaiser. 1997. Natural disasters and psychological adjustment: implications of research for intervention efforts. Journal of Psychological Practice 3:113-127.

Schmelzkopf, K. 1995. Urban community gardens as contested spaces. Geographical Review 85(3):364-381. http:/ /dx.doi.org/10.2307/215279

Segerstråle, U. 2000. Defenders of the truth: the battle for science in the sociobiology debate and beyond. Oxford University Press, Oxford, UK.

Shapiro, J. 2011. Evolution: a view from the 21st century. Financial Times Press Science, Upper Saddle River, New Jersey, USA.

Sideris, L. H. 2003. Environmental ethics, ecological theology, and natural selection. Columbia University Press, New York City, New York, USA.

Soulé, M. E. 1993. Biophilia: unanswered questions. Pages 441-455 in S. R. Kellert and E. O. Wilson, editors. The biophilia hypothesis. Island Press, Washington, D.C., USA.

Stedman, R. C., and M. Ingalls. 2012. Topophilia, biophilia and greening in the red zone. In K. G. Tidball and M. E. Krasny, editors. Greening in the red zone: disaster, resilience, and community greening. Springer, New York, New York, USA.

Sullivan, W. C., and F. E. Kuo. 1996. Do trees strengthen urban communities, reduce domestic violence? Northeastern Area State and Private Forestry, Urban Forestry Center for the Midwestern States, Evanston, Illinois, USA.

Svendsen, E., and L. Campbell. 2005. Living memorials project: year 1 social and site assessment. General Technical Report NE-333, U.S. Forest Service, Newtown Square, Pennsylvania, USA.

Tidball, K. G. 2012. Trees and rebirth: symbol, ritual, and resilience in post-Katrina New Orleans. In K. G. Tidball and M. E. Krasny, editors. Greening in the red zone: disaster, resilience, and community greening. Springer, New York, New York, USA.

Tidball, K. G., and M. E. Krasny. 2007. From risk to resilience: what role for community greening and civic ecology in cities? Pages 149-164 in A. E. J. Wals, editor. Social learning towards a more sustainable world. Wagengingen Academic Press, Wagengingen, The Netherlands.

Tidball, K. G., and M. E. Krasny. 2008. "Raising" urban resilience: community forestry in post-conflict and postdisaster contexts. Resilience 2008. Stockholm, Sweden.

Tidball, K. G., and M. E. Krasny. 2011. Toward an ecology of environmental education and learning. Ecosphere 2(2): art21. http://dx.doi.org/10.1890/ES10-00153.1

Tidball, K. G., and M. E. Krasny. 2012b. Introduction: greening in the red zone. In K. G. Tidball and M. E. Krasny, 
editors. Greening in the red zone: disaster, resilience, and community greening. Springer, New York, New York, USA.

Tidball, K. G., and M. E. Krasny, editors. 2012a. Greening in the red zone: disaster, resilience, and community greening. Springer, New York, New York, USA.

Tidball, K. G., M. E. Krasny, E. Svendsen, L. Campbell, and K. Helphand. 2010. Stewardship, learning, and memory in disaster resilience. Environmental Education Research (Special Issue: Resilience in social-ecological systems: the role of learning and education) 16(5-6):591-609. http://dx.doi. org/10.1080/13504622.2010.505437

Tidball, K. G., and E. D. Weinstein. 2011. Applying the environment shaping methodology: conceptual and practical challenges. Journal of Intervention and Statebuilding 5 (4):369-394. http://dx.doi.org/10.1080/17502977.2011.625787

Tidball, K. G., E. D. Weinstein, S. Kaisler, R. GrossmanVermaas, and S. Tousley. 2008. Stake-holder asset-based planning environment. Department of Defense and DOD/OSD 2007 STTR Topic 003 Final Technical Report. Washington, D.C., jointly published by Logos Technologies, Cornell University, and International Sustainable Systems: 114

Tukey, H. B., Jr. 1983. Urban horticulture: horticulture for populated areas. Horticultural Science 18(1):11-13.

Ulrich, R. S. 1983. Aesthetic and affective response to natural environment. Pages 85-125 in I. Altman and J. F. Wohlwill, editors. Behavior and the natural environment. Plenum Press, New York, New York, USA.

Ulrich, R. S. 1984. View through a window may influence recovery from surgery. Science 224:420-421. http://dx.doi.or $\mathrm{g} / 10.1126 /$ science. 6143402

Vale, L. J., and T. J. Campanella, editors. 2005. The resilient city: how modern cities recover from disaster. Oxford University Press, New York, New York, USA.

Van Den Berg, A. E., T. Hartig, and H. Staats. 2007. Preference for nature in urbanized societies: stress, restoration, and the pursuit of sustainability. Journal of Social Issues 63(1):79-96. http://dx.doi.org/10.1111/j.1540-4560.2007.00497.x

van den Born, R. J. G., R. H. J. Lenders, W. T. de Groot, and E. Huijsman. 2001. The new biophilia: an exploration of visions of nature in Western countries. Environmental Conservation 28(1):65-75. http://dx.doi.org/10.1017/S037689 $\underline{2901000066}$

Van Winsum-Westra, M., and T. A. D. Boer. 2004. (On)veilig in bos en natuur? Een verkenning van subjectieve en objectieve aspecten van sociale en fysieke veiligheid in bos- en natuurgebieden. [(Un)safety in forests and nature? An exploration of subjective and objective aspects of social and physical safety in forest and nature areas]. Altera, Wageningen, The Netherlands.

Vayda, A. P., and B. McCay. 1975. New directions in ecology and ecological anthropology. Annual Review of Anthropology 4:293-306. http://dx.doi.org/10.1146/annurev.an.04.100175.001453

Vining, J., M. Merrick, and E. A. Price. 2008. The distinction between humans and nature: human perceptions of connectedness to nature and elements of the natural and unnatural. Research in Human Ecology 15(1).

Vitousek, P. M., H. A. Mooney, J. Lubchenco, and J. M. Melillo. 1997. Human domination of earth's ecosystems. Science 277(5325):494-499. http://dx.doi.org/10.1126/scienc e.277.5325.494

Walker, B., S. Carpenter, J. Anderies, N. Abel, G. S. Cumming, M. Janssen, L. Lebel, J. Norberg, G. D. Peterson, and R. Pritchard. 2002. Resilience management in socialecological systems: a working hypothesis for a participatory approach. Conservation Ecology 6(1): 14. [online] URL: http ://www.ecologyandsociety.org/vol6/iss1/art14/

Walker, B., C. S. Holling, S. R. Carpenter, and A. Kinzig. 2004. Resilience, adaptability and transformability in socialecological systems. Ecology and Society 9(2): 5. [online] URL: http://www.ecologyandsociety.org/vol9/iss2/art5/

Walker, B., and J. A. Meyers. 2004. Thresholds in ecological and social-ecological systems: a developing database. Ecology and Society 9(2): 3. [online] URL: http://www.ecologyandso ciety.org/vol9/iss2/art3/

Walker, B., and D. Salt. 2006. Resilience thinking: sustaining ecosystems and people in a changing world. Island Press, Washington, D.C., USA.

Wallin, I. 1927. Symbionticism and the origin of species. Williams and Wilkins, Baltimore, Maryland, USA. http://dx. doi.org/10.5962/bhl.title.11429

Weinstein, E., and K. G. Tidball. 2007. Environment shaping: an alternative approach to applying foreign development assistance. Journal of Intervention and Statebuilding 1 (1):67-85. http://dx.doi.org/10.1080/17502970601075923

Wells, N. 2000. At home with nature: effects of "greenness" on children's cognitive functioning. Environment and Behavior 32(6):775-795. http://dx.doi.org/10.1177/00139160 $\underline{021972793}$

Wenger, E. 2003. Communities of practice and social learning systems. Pages 76-99 in D. Nicoline, S. Gherardi, and D. Yanow, editors. Knowing in organizations: a practice-based approach. M.E. Sharpe, New York, New York, USA. http://d x.doi.org/10.1177/135050840072002 
Wenger, E., R. McDermott, and W. M. Snyder. 2002. Cultivating communities of practice. Harvard Business School Press, Cambridge, Massachusetts, USA.

Williams, J. 2007. Thinking as natural: another look at human exemptionalism. Human Ecology Review 14(2):130-139.

Wilson, E. 1975. Sociobiology: the new synthesis. Harvard University Press, Cambridge, Massachusetts, USA.

Wilson, E. O. 1984. Biophilia. Harvard University Press, Cambridge, Massachusetts, USA.

Wimberley, E. T. 2009. Nested ecology: the place of humans in the ecological hierarchy. Johns Hopkins University Press, Baltimore, Maryland, USA.

Zhang, D. D., P. Brecke, H. F. Lee, Y.-Q. He, and J. Zhang. 2007. Global climate change, war, and population decline in recent human history. Proceedings of the National Academy of Sciences 104(49):19214-19219. http://dx.doi.org/10.1073/ pnas.0703073104 